\title{
MAJANDUSE OSKUSSÕNU KAHE MAAILMASÕJA VAHELT
}

\author{
JAAN ALVER, LEHTE ALVER
}

\begin{abstract}
Annotatsioon. Artiklis vaadeldakse eestikeelse majandusterminoloogia arengut aastail 1900-1940. Seejuures keskendutakse kahe maailmasõja vahelisele perioodile, mis algas Eesti Vabariigi ja eestikeelse ülikooli tekkimisega ning lõppes Eesti riigi kadumisega. Ettevõtlust käsitleva kirjanduse (millest suurema osa moodustab raamatupidamisalane kirjandus) kronoloogiline analüüs võimaldab jälgida oskussõnade ilmumist ja arenemist.
\end{abstract}

Võtmesõnad: eesti keel, majandus, raamatupidamine, terminoloogia

\section{Sissejuhatus}

Tartu Ülikool taasavati 1802. aastal kui saksa(keelne) ülikool. Kuigi majandusaineid õpetasid kõrge kvalifikatsiooniga õppejõud, olid loengud saksa keeles. Järgnevalt põgusalt mõnest tuntumast õppejõust.

Ülikooli ökonoomika, tehnoloogia ja arhitektuuri õppetooli esimene professor oli ülikooli arhitekt Johann Wilhelm von Krause (ametis 1803-1828), kes õpetas õllepruulimise, viinaajamise, tärklisevalmistamise, tõrvaajamise, lubjapõletamise ning nahaparkimise kõrval ka põllumajanduse ökonoomikat ja raamatupidamist (J. Alver, L. Alver 2011a: 595).

Saksa päritolu majandusteadlane ja kirjanik Friedrich Eberhard Rambach oli kameraalteaduste, rahanduse ja kaubanduse õppetooli esimene korraline professor (ametis 1803-1828). Ta pidas loenguid riigimajanduse, merkantilismi ja füsiokratismi kriitika, rahvamajanduse põhialuste, rahvatulu analüüsi, finantsteaduse ja kaubanduspoliitika kõrval ka asjaajamise stiili, maksunduse, raharingluse ja veksliasjanduse, panganduse ning raamatupidamise kohta (J. Alver, L. Alver 2011b: 292).

Rambachi järglaseks sai Eberhard David Friedländer, kes oli kameraalteaduste, rahanduse ja kaubanduse professor aastail 1828-1853. 
Ta õpetas neidsamu õppeaineid (riigimajandus, rahvamajandusteooria, finantsteadus, pangandus, raharinglus, makseinstrumendid, raamatupidamine, veksliasjandus jt), mida eelkäijagi, kuid lisaks veel kaubandusteadust, põllumajandusstatistikat, poliitilist ökonoomiat, poliitilist aritmeetikat jm ning pidas kameralistika praktikumi (J. Alver, L. Alver 2011a: 307).

Aastail 1856-1869 oli kameraalteaduste korraline professor Tartu Ülikooli kandidaadikraadiga lõpetanud ja seejärel seal ka magistritöö kaitsnud Riiast pärit sakslane Johann Theodor Grass, kes õpetas poliitilist ökonoomiat, rahandust, kaubandusteadust, kaubanduse ajalugu, statistikat ning korraldas kameralistika praktikume. Grassi töötamise ajal nimetati kameraalteaduste, rahanduse ja kaubanduse õppetool ümber poliitilise ökonoomia õppetooliks (Hagelberg, Sõrg 2003: 67).

Aastail 1865-1868 oli kameraalteaduste, rahanduse ja kaubanduse õppetooli (1866. aastast etnograafia, geograafia ja statistika õppetooli) professor hilisem kuulus majandusteadlane ja poliitik Adolph (Adolf) Gotthilf Heinrich Wagner, kes õpetas maksunduse ja riigivõla üldajalugu; krediiti ja krediidiasutusi; väliskaubanduse võrdlevat statistikat; võrdlevat finantsstatistikat; majanduspoliitikat ja poliitilist ökonoomiat (J. Alver, L. Alver 2011b: 637). Pärast Wagneri lahkumist oli aastail 1869-1873 geograafia, etnograafia, statistika ja poliitilise ökonoomia professoriks Ernst Louis Etienne Laspeyres. Ülikoolis töötamise ajal õpetas ta statistikat; statistika ajalugu, teooriat ja tehnikat; aktsiaseltside, kaubanduse, tööstuse, rahanduse, panganduse, põllunduse ja metsanduse statistikat; teoreetilist poliitökonoomiat; rahandusteadust; raha-, laenu- ja pangapoliitikat ning -statistikat jm. Tartu perioodil lõi Laspeyres agregaatindeksite teooria, mida kasutatakse majandusstatistikas ja -analüüsis tänini (J. Alver, L. Alver 2011a: 646).

1880. aastatel alanud venestamine tõi kaasa venekeelse õppe. Majandusaineid õpetas slaavlaste (peamiselt venelaste) kõrval ka mõni vene keelt valdav baltisakslane. Paraku pole vene perioodi majandusõppejõududest teadussaavutuste poolest kedagi esile tõsta. Küll aga on huvitav märkida, et aastail 1912-1915 töötas ülikoolis eradotsendina maailmakuulsa vene päritolu USA majandusteadlase, Nobeli majanduspreemia laureaadi Vassili (Wassily) Leontjevi (Leontiefi, Leontieffi) isa, hilisem majandusprofessor Vassili Leontjev, kes õpetas poliitilist ökonoomiat ja statistikat (J. Alver, L. Alver 2011a: 655). 
Enne eestikeelse rahvusülikooli avamist toimus õppetöö saksa või vene keeles. Ühtki eestlasest majandusõppejõudu saksa- ja venekeelses ülikoolis polnud. Tuleb nentida ülikooli ja selle õppejõudkonna (sh majandusõppejõudude) olulist panust Eesti- ja Liivimaa arengule, ent kui rääkida eestikeelsest majandusteadusest ja -kirjandusest ning oskussõnavarast, oli ülikooli panus olematu. Siiski ilmus 1907. aastal eesti keeles kaks tähelepanuväärset teost: vene sotsiaaldemokraadist filosoofi, majandusteadlase ja publitsisti Aleksandr Bogdanovi 1897. aastal üliõpilasena publitseeritud raamatu „Краткий курс экономической науки“ eestikeelne tõlge „Lühikene majanduseteaduse õpetus“ ja Hans Pöögelmanni „Majandusteaduse õpetus“. Nende trükiste kohta märgib Uno Liivaku järgmist:

„Milliste karide vahel tõlkijad veel tollalgi seilama pidid, ilmneb ehk ühest „Eesti Kirjanduse“ retsensioonist, milles võrreldakse Pöögelmanni „Majandusteaduse õpetuse“ I osa ja Bogdanovi „Lühikese majanduseteaduse õpetuse" tõlke oskussõnavara."

Edasi tsiteerib Liivaku retsensenti August Hankot ${ }^{1}$ : ,, Raamatu kirjutaja [Pöögelmann] on pidanud hulk uusi sõnu tarvitusele võtma; näituseks „tööndus“(Betrieb), „,ööpõnevus“(Intensität), „Hoogsiht“"(Tendenz) jne. [---] Nüüd valitseb meie teaduslikus keeles suur korratus. Igal kirjanikul on oma isekeel. Näituseks tarvitab A. Bogdanovi „Majanduseteaduse õpetuse“ tõlkija siin teisi nimetusi. „Intensität" on temal ,intensivsus“, „Tendenz“ - „tendents ehk kalduvus, püüe“; Saksa sõna „Produktivität““ tõlgib ta sõnaga „töö sigivus ehk produktiivsus“. H. Pöögelmann tarvitab siin sõna „sigitavus“, ja igatahes on see õigem, sest töö ei ole mitte sigiv, vaid sigitav."

Olgu märgitud, et Bogdanovi raamatu tõlkija oli hilisem tuntud majandusteadlane, poliitik, pangandustegelane ja diplomaat Nikolai Köstner, kes oli sel ajal kõigest 18-aastane. Võib ette kujutada, milliste keele- ja terminoloogiaprobleemidega tuli noorel majanduspoliitikahuvilisel rinda pista. Eestikeelse puuduliku oskussõnavara tõttu on ta kasutanud hulgaliselt germanisme: „antagonismus“, „fetishismus“, „indiwidualismus“, „kommunismus“, „konserwatismus“, „organismus“, ja russitsisme: ,assignatsia“, „,doktrina“, ,politika-ökonomia“, „,reglement“, „territoria“ jt. Sõna „tootmine“ asemel on läbivalt kasutatud „walmistamine“. Raamatu lõppu lisatud „Raskemate sõnade seletusest" leiame sellised primitiivsed

${ }^{1}$ August Hanko, Seadus, ühiselu, majanduse-teadus. - Eesti Kirjandus 1908, 1, 59. 
definitsioonid nagu „teoria - õpetus“, ,termin - asja nimetus“, „,̈konomika - kokkuhoidmine, maapidamise õpetus“ (Bogdanow 1907: 392).

\section{XX sajandi algus}

Põgus pilk XX sajandi esimese 40 aasta eestikeelsele majanduskirjandusele näitab, et kõige rohkem ilmus raamatupidamisalaseid brošüüre ja õppevahendeid. Kuna raamatupidamiskohustus tulenes seadus(t)est, siis õpetati seda nii kohalikes kommerts- ja majanduskoolides kui ka mitmesugustel kursustel. Seepärast oli nõudlus raamatupidamisalase kirjanduse järele suur. Kui võtta arvesse, et pärast rahvusülikooli avamist 1. detsembril 1919 anti õppejõudude enamiku moodustanud mitte-eestlastele kümme aastat aega üleminekuks eestikeelsele õpetamisele, on selge, miks eestikeelsete ökonoomikaalaste teaduslike originaaltrükiste ilmumine venis.

Esimesed eestikeelsed raamatupidamisalased brošüürid ilmusid teadaolevalt 1900. aastal (Linnaks 1983: 36). Nendeks olid V. K. Sepa „Kodune raamatupidamine iga ühele“ ja Jaak Reichmanni „Talu äriraamatud“. Tollasest (eriala)keelest annab ettekujutuse järgmine katkend (Reichmann 1900: 8-9):

„Tabeliks nimetatakse niisugust paberi poognat ehk üht jagu temast, mis kriipsude läbi mitmesse jakku on jaotatud. .. Tabelisi on kahesuguseid. Ühed nendest kannavad otsa peal ladinakeelset sõna „Debet“, see tähendab Eestikeeles: mis mina teiste käest saanud olen, ehk teise sõnaga, mille eest ma teistele maksma pean; teiste pealkiri on „Kredit“, s. t. mis mina teistele annud olen ehk mis teistel mulle maksta on. Kui meie nende wõerakeelsete ajasõnade asemele sündsad eestikeelsed sõnad seadime, siis tähendab debet - saanud ja kredit - annud.“

Joonealuse märkusena on lisatud: „Mõned raamatupidajad tarwitawad ajasõnade debet ja kredit asemel nimesõnu sissetulek (debet) ja wäljaminek (kredit), ka tulu ja kulu.“ (Reichmann 1900: 9)

Tollastest oskussõnadest saab ülevaate Reichmanni bilansiskeemi põhjal (Reichmann 1900: 10; vt allpool): „Waranduse üleskirjutamine äriaasta algul on esimene töö, mida raamatupidaja peab ette wõtma. See töö tuleb hoolega ja kindla plaani järele toimendada, et midagi silmade wahele ja üleskirjutamata ei jääks. Siin tuleb terwe talu warandus majanduse kapitalide järele ära jaotada ja iga asjale tema praegune wäärtus juurde kirjutada.“ 


\begin{tabular}{|l|l|l|}
\hline Aktiv (Meie omandus) & \multicolumn{2}{|}{} \\
\cline { 1 - 2 } A. Seisaw ehk põhjuskapital & I. & Maa kapital \\
\hline & II. & Hoone kapital \\
\hline B. Seisja liikuv kapital (Inventar) & \multicolumn{2}{|l|}{} \\
\hline & III. & Elaw kapital \\
\hline & IV. & Surnud kapital \\
\hline D. & V. & Liikuv kapital \\
\hline Passiv (Teiste omandus) & & \\
\cline { 1 - 1 } 1. Wõlad & & \\
\cline { 1 - 1 } 2. Maksud ja kohused & & \\
\cline { 1 - 2 } &
\end{tabular}

„Maa kapitali“ koosseisus tuli Reichmanni järgi näidata „maa wäärtus“, „maa õigused“ ja „maa parandamised“ (melioratsioon). „Hoone kapitali““ moodustasid „ehitused (hooned, sillad, aidad jne.)“. „Elawaks kapitaliks“ nimetas Reichmann „loomi (hobuseid, weiseid, sigu jne.)“. „Surnud kapitali“ koosseisus eristas Reichmann kahte rühma: „masinaid ja riistu (tööriistad, sõiduriistad jne.)“ ning ,,metsi, puuistandusi jne.“. „Liikuva kapitali“ moodustasid „sularaha ja nõudmised“, „põllu ja heinamaa saadused (wili, seemned, juurewiljad, heinad jne.)“ ning ,loomariigi saadused ja mitmesugune muu materjal (liha, rasw, sool, kalad, willad, nahad, sõnnik jne.)“.

Konto mõiste tehti lugejale selgeks järgmiselt (Reichmann 1900: 15-16):

„Konto on wõerakeelne sõna, mida igalpool äriraamatutes tarwitatakse. Tema tähendab umbes niisama palju kui rehnung. Tahame teada, kui palju meile üks hobune aastas kasu toob, siis teeme sellest rehnungi. Ühe paberi lehe peale kirjutame kõik need raha summad, mis hobune meile sisse on toonud - andnud (kredit), olgu see põllutöö, (tööpäewad) woori wedamisega ehk m. m.; teise lehe peale kirjutame jälle need summad mis hobune meilt on saanud (debet) s. o. mis tema pidamine meile selle aja sees maksma on tulnud. Wõrdleme nüüd neid summasid isekeskes, siis on see täielik rehnung, mida raamatupidajad lühidalt kontoks nimetavad. Niisuguseid rehnungisid wõi kontosid wõib raamatupidaja oma soowi järele nii palju walmistada kui ta tarwiliku näeb olewat.“

1903. aastal ilmus Saksamaal Görlitzis kommertskooli direktorina töötanud Friedrich Schubitzi (Scubitzi) raamat „Kahekordse Italia 
Raamatupidamise õpetus", mida professor Erik Linnaksi hinnangul võib pidada esimeseks eesti keeles ilmunud raamatupidamise teooriat käsitlevaks õpikuks (Linnaks 1983: 37). Schubitzi raamatu eessõnas märgib tõlkija A. Tattar: „Juba ammu on soowisid awaldatud, et ka Eesti keeles kahekordse raamatupidamise õpetus ilmuks, mille järele võimalik oleks kahekordset raamatupidamist ära õppida. Olgu ka, et küll wõerastes keeltes väga mitmed niisugused õpperaamatud ja igasugune arvuteadusline kirjandus on - ei või sellest ometi kõik kasu saada, sest wõera keele järele õppimine nõuab ühelt poolt põhjalikku keeletundmist, teiselt - teeb see takistusi kui kahekordset raamatupidamist sisse tahetakse seadida, et asjakohaseid sõnu ja nimetusi ei leita. Pealegi on igal õppijal oma emakeeles kõige parem ja kergem niisugusest asjast aru saada.“ (Scubitz 1903: 3)

Schubitzi raamatut sirvides on näha, et tõlkija Tattar on pidanud looma eestikeelseid oskussõnu, sest seni teadaolevad varasemad väljaanded olid tunduvalt elementaarsema sisuga. Tema oskussõnad on pigem seletavad üldkeelendid kui terminid. Olgu märgitud, et Tattarilt ilmus aasta varem 22-leheküljeline brošüür „Põlluasjanduse raamatupidamise õpetus“, kus ta muuhulgas märkis, et, inwentur ehk waranduse üles wõtmine jaguneb kahesse osasse, s. o. activasse ja passivasse“, eristades esimeses ,liikumata warandust“ ja ,liikuwat warandust“" (Tattar 1902: 7).

\section{Eestikeelse oskussõnavara loomine algab}

Keelekorraldusliikumine, mille kõrgaeg oli aastail 1920-1935, mõjutas ka majandusalast erialakirjandust ja oskussõnavara. Seejuures tuleb märkida, et eestikeelse majandusalase oskussõnavara areng kahe maailmasõja vahel leidis väljundi eeskätt raamatupidamises. See on ka arusaadav. Uus riik vajas eelkõige riigikeelseid seadusi ja juhendmaterjale. Raamatupidamine on majandusteadustest kõige rakenduslikum ja juriidilisem, sisaldades nii majanduslikku kui ka juriidilist aspekti. Raamatupidamine on tihedalt seotud pangandus-, finants-, maksu- ja äriõigusega, raamatupidamisse on väljund paljudel seadustel. Raamatupidamise väljundeid - finantsaruandeid - kasutavad paljud huvirühmad: majandusanalüütikud ja -nõustajad, olemasolevad ja potentsiaalsed investorid, finants- ja krediidiasutused, maksu- ja statistikaamet, muud riigivõimuorganid. Seepärast on igati mõistetav, miks aastail 1920-1940 ilmunud majanduskirjandusest 
moodustas valdava osa (autorite hinnangul 80-90\%) raamatupidamisalane kirjandus. Raamatupidamiskirjandusest on pärit ka paljud terminid, mida kasutati ettevõttemajanduse õpetamisel.

Eduard Karlsoni 1920. aastal ilmunud „Kahekordne ehk Itaalia raamatupidamine“ jätkas lihtsakoelise lühibrošüürina juba väljakujunenud traditsiooni. Oskussõnade puhul võib märgata kohati vene keele mõju „Aktiiva“, „Passiiva“, „debitoor“, „kreditoor“ (kuid „deebet“ ja ,kreedit“). Huvitavatest oskussõnadest võib märkida „Aktiiva“ sünonüümi „Pärisomandus“ ja sõna „maksutermin“ (viimane tähendas maksetähtpäeva). Esimesed raamatud ilmusid Johannes Tammelt (1921, 1923), kes hiljem muutis oma nime Tammoks. Tammo oli üliõpilasena õppinud raamatupidamist Kopenhaageni Ülikoolis ning tegu oli kõrge kvalifikatsiooniga spetsialistiga ${ }^{2}$. Tema raamatutes oli palju uusi või vähetuntud termineid: „ärivarandus“ ehk ,„ärikapitaal“", mis jagunes ,aktiva-varanduseks“ ja „passiva-varanduseks“; ,puhtvarandus“ ehk ,puhtkapital“, „kollektiivarve“ ehk „kogujaarve“ (sünteetiline konto), „ärisõber“ (klient), ,liikuv varandus“ ja „liikumatu varandus“ (vallasvara ja kinnisvara), „huupikauplus“ (hulgikauplus) ning ,jaotikauplus“ (jaekauplus), „positiiv-õigus“ (võõras võlg) ja „negatiiv-õigus“ (oma võlg) jpt.

Tartu kommertskooli majandusteaduse ja reaalkooli ajaloo õpetajalt, hilisemalt koolidirektorilt Johannes Adamsonilt ilmus 1922. aastal (teine trükk 1926) õpperaamat „Majandusteadus“, mis oli mõeldud „nii keskkoolidele kui ka eneseharimiseks“. Oma raamatus eristas ta põhikapitaali ja liikuvkapitaali (Adamson 1922: 47), samuti ,produktiivset“ ja „,surnud kapitaali“, ,ühiskondlikku“ ja ,erakapitali“ ja ka ,alalist“ ja „muutuvat kapitali“ (Adamson 1922: 48-49). Samal ajal kasutas ta ka terminit „kapital“ (Adamson 1922: 48). Ettevõtted liigitas ta ,isiklisteks“ ja ,kollektiivseteks“ (Adamson 1922: 75). Kollektiivettevõtted olid ,täisühingud“, ,piiratud“ ehk ,,usaldusühingud“" ning ,,aktsiaühingud“(Adamson 1922: 76). Nende äriühinguvormide nimetused leiab ka praegusest Eesti äriseadustikust.

2 Akadeemik Uno Mereste, kes oli üks paljudest Johannes Tammo (kutsuti ka Tammo Jussiks) õpilastest, meenutab teda tänuga oma mälestustes. See on eriti mõistetav, teades, et kui Mereste asus 1950. aastal pärast Tallinna Tehnikaülikooli (siis Tallinna Polütehniline Instituut) lõpetamist tööle Tallinna Rahanduse ja Krediidi Tehnikumi (mille ta ise oli neli aastat varem lõpetanud, kui see kandis teistsugust nimetust), tuli tal hakata õpetama Tammo asemel, kes just sel aastal siirdus vanaduspensionile. 
Sõjaeelse Eesti Vabariigi tuntumaid raamatupidamisspetsialiste oli Johannes Jostoff. Jostoffi tuntust ja kõrget kvalifikatsiooni iseloomustas fakt, et pankade ja ettevõtete raamatupidajad, kel oli probleeme bilansi koostamisega, pöördusid viimases hädas tema poole. Lisaks oli ta ka paljude erialatrükiste autor. Tema 1923. aastal ilmunud raamatus „Kaubanduse korrespondents" on eraldi osa „Oskus- ja võõrsõnade seletus“ (Jostoff 1923: 181-182). Keeleliselt on raamatus kasutatud oskussõnadest ja üldkeelenditest huvitavamad järgmised: „ettus“ (ettepanek), „hinnastik“ (hinnakiri), „,koostus“ (koosseis), „krediteerima“ ehk „hüvistama“, „maksus“ (maksumus), „oodustama“ (diskonteerima), ,presentant“" (veksli ettenäitaja), „sesong“ (hooaeg), ,teadumus“ (kogemus, elutarkus), „teisik“ (ärakiri, koopia), „toimend“ (tehe, äriline käik, operatsioon), „transfert“ (rahasaate käsukiri), „tugema“ (ennast toetama), „tulemed“ (sissetulekud), „tõsistama“ (tõeks tegema), ,üttama“ (kellegi poole end pöörama).

Esimeseks heal tasemel kirjutatud raamatupidamise originaalõpikuks eesti keeles oli majandusteadlase Lilli Ibruse 1922. aastal ilmunud „Raamatupidamise õpiraamat“, mis oli kirjutatud väga ladusas keeles. Mõned näited Ibruse oskussõnavarast: „,isikline ettewõte“ (tänapäeval füüsilisest isikust ettevõtja ehk FIE), „kasu“ (kasum), „kahju“ (kahjum), „,protsendiarwe“ (intressikonto), ,tagavarakapital“ (reservkapital). Täiesti tänapäevaselt kõlavad „täisühing“ ja „piiratud ühing“ (usaldusühing). Kuna tegu on esimese korraliku eestikeelse raamatupidamisõpikuga, on mõistlik tutvustada selle autorit, seda enam, et tegu on värvika isiksuse ja aktiivse ühiskonnategelasega. Liina (Lina, Lilli) Ibrus-Köstner (Varus) õppis aastail 1907-1913 Moskva kaubandusinstituudis, kus lõpetas pangandusosakonna kandidaadikraadiga. Enne Moskvasse siirdumist oli ta aktiivne sotsiaaldemokraat, osales illegaalses poliitilises tegevuses, pidas kõnesid nais- ja sotsiaalküsimusist. Aastail 1913-1917 töötas Ibrus raamatupidajana Hugo Stinnese firma Peterburi osakonnas, 1918-1920 sekretärina Eesti saatkonnas Pariisis. Aastail 1921-1923 õppis Ants Laikmaa ateljees maalimist, 1925-1927 töötas raamatupidajana, 1927-1928 Eesti Vabariigi Riigikontrolli teenistuses, alates 1928. aastast Pikalaenu Pangas jaoskonnajuhataja abi. 1931. aastal oli ta Arveasjanduse Revidentide Ühingu asutajaid. Ibrus oli ka mitme ajalehetoimetuse liige ning tõlkis eesti keelde populaarteaduslikku kirjandust. Aastail 1912-1921 oli ta abielus Nikolai Köstneriga. 
Uusi majanduse oskussõnu ilmus nii õpikutesse kui ka sõnastikesse. Üldsõnastike kõrval hakati välja andma ka erialasõnastikke. 1923. aastal ilmus Leonhard Sõerdi „Eesti keeles tarvitusel olevate võõrakeelsete sõnade sõnastik“. Raamatu eessõnas märgib koostaja (Sõerd 1923):

„Kuna meil, Eestis, tarvitusel olevate võõrakeelsete sõnade uputusest ülepääsemiseks senini mitte midagi ära tehtud ei ole, tuleb oletada, et ajalehe ja kirjanduse lugejate ringis tarvidus võõrakeelseid sõnu äraseletava sõnastiku järele on piiramata suur.

Sellele nõudmisele vastu tulles, püüame käesoleva sõnastiku ilmutamisega lugejaid tarvitusel olevate võõrakeelsete sõnade uputusest päästa."

Sõerdi sõnastikus on ka majanduse oskussõnu: „brutaalne - brutto kaalus“; „debet - raamatupidamises „võlg“, saada olev võlg; äri- ehk raharaamatu vasem pool, kuhu kirjutatakse sissetulek“; „deposiitor riiete, väärtasjade jne. laenuleandja“; , diferent - vahe kauba tellimishinna ja päralejõude hinna vahel“"; „fond - 1) põhikapitaaliga kindlustud väärtpaberid; 2) põhikapitaali moodustav väärtuste kogu; 3) põhi, pind“"; ,krediit pank - pank, kust raha laenu peale välja antakse“. Sõerdi võõrsõnastikust sai päris korralikku teavet ka „teooria“, „termini““ ja „terminoloogia“ kohta: „teooria - 1) teadmine, mis loogiliselt järeldatud üldistest seadustest; 2) mingisuguse teaduse või kunsti seadus, väljaspool praktilisi katseid; 3) passiivne vahekord tõeoludega, praktika vastand“; „termiin - 1) mingisuguse teadusharu oskussõna; 2) tähtaeg“; „terminoloogia - mingisugusesse teadusharusse jne. puutuvate termiinide kogu“.

Georg Grafilt, kes hiljem eestistas oma nime Heino Tähisteks, ilmus 1923. aastal „Raamatupidamise õpetus kirjateel“. Grafi raamatu omapäraks on põhiteksti lõppu lisatud lühisõnastik (22 terminit) „Wõõrakeelsed kaubandusteaduslised oskussõnad“. Paraku oli temagi üks neid autoreid, kes kasutas mõnikord russitsisme - näiteks „,aktiv“ ja „passiv“ (lisaks variandid „Aktiwa“ ja „Passiwa“ ning „Aktiva“ ja „Passiva“), loenguid nimetas ta „lektsiateks“. Tollast kõnepruuki iseloomustab sõnade „näide“ ja „näited“ asemel vastavalt sõnade „näite“ ja „näitused“ kasutamine, samuti järgmine katkend (Graf 1923: 6):

„Kaubad jagunewad oma iseloomu poolest kahte liiki: reaalsed ja ideaalsed kaubad. [---] Ärimehed, kes reaalsete kaupadega tegemist teewad, nimetatakse - kaupmeesteks, ideaalsete kaupadega äriajajad pangapidajateks ehk pankiirideks." 
Vahetult enne lõppsõna kirjeldas autor raamatupidamisregistrit, mida muudes allikates ei esine - „Salaraamatut“" (Graf 1923: 146):

„Nagu selle raamatu nimetus juba näitab, peetakse selles raamatus mõned kõrwalised operatsioonid, mis peremees ise ehk tema wolinik teeb ja teiste ametnikkude ja teenijate eest saladuses hoitakse. Seda raamatut peab peremees ise ehk isik, keda ta selle jaoks usaldab. ... . Maksuinspektorile tuleb see raamat tema nõudmise peale niisama ette näidata kui teisedki äriraamatud.“

Raamatu lõppsõnas iseloomustas Graf tollast raamatupidamise hetkeseisu järgmiselt (Graf 1923: 147):

„Paraku pean aga toonitama, et meie erikirjandus selle alal wäga waene on ja ainukene õperaamat, mis tänini raamatupidamise alal ilmunud, on Tamme oma, mida Teile soowitada võin. Kõik teised teosed Teile midagi huwitawat ja uudist ei paku.“"

Graf rõhutas, et tuleb eristada termineid ,kreedit“ ja ,krediit" (Graf 1923: 28):

„Kredit - on andmine ja räägitakse wälja - kreedit. Krediit - on wõlg, näit. Krediit-Pank on seega Wõlapank (ehk wõlgu andja pank).“

Erialatrükiste autorite hulgas oli ka väga mainekaid riigitegelasi. Nii ilmus 1929. aastal Johan (ka Johann, Juhan) Kuke „Raamatu- ja arvepidamise käsiraamat". Selles raamatus on tarnijaid (tollases kõnepruugis „hankijaid“) nimetatud kaubamuretsejateks, aktivakontot aktiiv arveks (J. Kukk 1929: 58) ja passivakontot passiiv arveks (J. Kukk 1929: 48). Selle asemel, et märkida ,tegu on passivakontoga“, on raamatus ,arve on passiivne“" (J. Kukk 1929: 49).

Majandusteadmisi andvates Eesti õppeasutustes domineeris nii nagu mujalgi seisukoht, et koolitada tuleb laia profiiliga spetsialisti - ettevõtte ökonomisti. Majandustermineid kasutati ja oskussõnavara arendati ka sellistes õppeainetes nagu „Kaubanduse korrespondents“, „Kaubanduskirjavahetus“, „Äriline kirjavahetus“, „Kaubandusaritmeetika“, ,Finantsmatemaatika".

3 Johan Kukk (13. I 1885 - 4. XII 1942) osales Eesti iseseisvumisel iseseisvusmanifesti koostamises, oli aastail 1918-1920 Eesti Vabariigi esimene rahandusminister ja 1920-1922 kaubandus-tööstusminister, 1920-1926 Riigikogu liige ja 1921-1922 ka selle esimees, 1922-1923 riigivanem, 1924-1926 Eesti Panga direktor. NKVD vangistas ta 1941. Kukk hukkus vangilaagris. 
Nikolai Puura 1929. aastal ilmunud raamatus „Kaubandusaritmeetika“ on väärtpabereid nimetatud ,effektideks“ ning tänapäeval tuntud intressimäära asendas oskussõna ,protsenditaks“. Raamatus on kasutatud veel selliseid termineid nagu ,nimesväärtus“ (nimiväärtus) ,kauba-arvatlus“, „ostu-, müügi- ja tootmisarvatlus“, ,liht- ja liitarvatlus“, „otsekohesed kulud" (otsekulud). Väärtpaberi hinna ja nimiväärtuse erinevust tähistasid „aažio“ ja „disaažio“ (Puura 1929: 121). Olgu märgitud, et „,aažio“ oli pärast pikka vaheaega uuesti Eestis kasutusel aastatel 1991-2002 (alates 1. jaanuarist 2003 on see asendatud terminiga ,ülekurss“").

Eduard-Aleksander Mossi kaubandusaritmeetika õppevahendist (Moss 1930) võib leida termini ,protsendiraha“ (intress), ,nominaalväärtuse“ sünonüümina „nimiväärtuse“ ja lisaks „,päevaväärtuse“ ehk „kursiväärtuse“ (hind, millega väärtpabereid müüakse või ostetakse). Veel eristas Moss termineid „tulu“ ja „tuluvus“, kusjuures esimene oli väljendatud kroonides, teine protsentides. Obligatsioonide kustutamist nimetas Moss „tiraažiks“. Oma 1931. aasta „Kaubandusaritmeetika“ õppevahendis kasutas ta termini „,deebet“ sünonüümina „,võlastut“ ja „kreediti“ sünonüümina „hüvistut“ (Moss 1931: 19). Viimaseid termineid kasutasid 1930. aastatel ka paljud teised.

\section{XX sajandi kolmekümnendad aastad}

Esimesed eestlastest majandusõppejõud (Nikolai Köstner, Eldor Fählmann) jõudsid ülikooli alles 1920. aastate teisel poolel. Seepärast on igati loogiline, et eestikeelsed ökonoomikaalased teaduslikud originaaltrükised ilmusid alles 1930. aastatel. Sellesse perioodi jääb ka raamatupidamisalaste trükiste keele ja sisu märgatav parenemine ning esimeste erialaste oskussõnastike ilmumine.

XX sajandi neljas aastakümme algas kaubandusteadlase, ajakirjaniku ja leksikograafi Herbert Haljaspõllu (kuni 1921. aastani Grünfeldt) „Võõrsõnade leksikoni““(Haljaspõld 1930) ilmumisega, mille kordustrükk tuli 1931. aastal. Herbert Haljaspõldu võib pidada omamoodi nähtuseks Eesti 1930. aastate leksikograafias. Temalt ilmus iga paari aasta järel mõni sõnastik (Haljaspõld 1930, 1933, 1935, 1937a, 1937b). Eriti hinnatav on tema majandussõnastik „Ärielu manuaal I“ (Haljaspõld 1935), kuid palju majanduse oskussõnu on ka tema muudes sõnastikes. Haljaspõllu loodud sõnad on „tulundusteadlane“ (ökonomist), „etvima“(ette võtma, üritama), 
„etve“ (ettevõte), ,etvija“ (ettevõtja), „minem“ (müük laiemas mõttes), „tarbvara“" (vallasvara).

1931. aastal ilmus N. Rittichi raamat „Praktiline raamatupidamine iseõppimiseks", mille lõpuosas on väike kaubandussõnastik. Ka Rittich kasutas substantiive „võlastu“ ja „hüvistu“, kuid erinevalt Mossist vastavalt bilansi aktiva ja passiva tähenduses. Seevastu verbid „võlastuma“ (debiteerima) ja „hüvistama“ (krediteerima) seostas ta deebeti ja kreeditiga (Rittich 1931: 7). Rittich on oma raamatus kasutanud veel selliseid oskussõnu nagu ,,avanss“ ehk „,ede“ või „edesraha“, „,edis“ (kautsjon), „,daatoveksel“ (veksel, millel tähtaeg määratud), „kalkuleerima“ ehk „,arvatlema“, „solventne“ (maksevõimeline), ,suksessiivne“ (järk-järgult, järjekordne).

Aasta 1935 kujunes väga viljakaks keeleaastaks. Selle aasta üks suursündmusi oli „Äriettevõtete raamatupidamise keele seadus“, mis hakkas kehtima 1. jaanuaril. Selle seaduse kohaselt pidid kõik raamatupidamiskohustuslased alates 1. jaanuarist 1935 hakkama raamatuid pidama eesti keeles (seni võis raamatuid pidada ükskõik mis keeles, v.a heebrea keeles). Eesti keeles pidid olema kõik dokumendid, mida raamatupidamiskohustuslane koostas ning mis olid aluseks sissekannete tegemisel raamatupidamises. Maksuametil oli õigus kõik raamatud, mis ei vastanud raamatupidamise keele seaduse nõuetele, maksumenetlusest kõrvaldada. Kui dokumendid, mis pidid olema eesti keeles, olid võõrkeelsed, võis maksuamet nõuda teatud tähtpäevaks ametlikult tõestatud tõlget. Kui raamatupidamiskohustuslane seda nõuet ei täitnud, võis maksuamet lasta need dokumendid ära tõlkida ja nõuda hiljem raamatupidamiskohustuslaselt tõlkimiskulude katmist. Erandiks olid ettevõtted, mis töötasid kontsessiooni alusel, kui enamik nende aktsiatest/osatähtedest kuulus välismaisele ettevõttele või kui kontsessialused ettevõtted olid välismaiste ettevõtete osakonnad. Lisaks võisid teatud tüüpi ettevõtted, mis asusid kohaliku omavalitsuse piires, kus elanike enamiku moodustas vähemusrahvus, arvepidamist ning kirjavahetust pidada vähemusrahvuse keeles.

Majandusterminoloogia tähtsündmuseks kujunes majandussõnastiku „Valimik majanduslikke oskussõnu“ ilmumine, mille koostamisse olid kaasatud ka Elmar Muuk ja Johannes Voldemar Veski. Sõnastiku saamisloost on kõige paremini kirjutatud selle eessõnas (VMO 1935: 5-6): 
„Käesoleva oskussõnastiku koostamise kavatsus tekkis Eesti Tarvitajateühisuste Keskühisuse kodukordade komisjonis seoses tarvitajate- ja majandusühingute organiseerimise ja asjaajamise käsiraamatu „Ühiskaubanduse korraldus"väljaandmisega. Kavatsuse teostamiseks moodustati komisjon. [---] Esialgse kavatsuse kohaselt pidi sõnastik sisaldama ligikaudu 300 vajalisemat sõna majanduse alalt. Juba komisjoni töö tulemusena paisus sõnastik enam kui poole suuremaks. Hiljem täiendasid seda veel R. Paabo, J. Nihtig, K. Reinmann, H. Peetrimägi, V. Salomon, N. Jung, T. Könberg, G. Redi jt.

Komisjon oma töö lõpetanud ja tehtud täiendused arvestanud, andis käsikirja läbivaatamiseks E. Muugile, kes saatis selle peale hoolikat läbitöötamist ühes oma märkustega Akadeemilisele Emakeele Seltsile. Sealt tuli käsikiri tagasi J. V. Veski parandustega ja mõningaid eriarvamusi sisaldava kaaskirjaga. Ühtlasi saadeti käsikiri läbivaatamiseks ka Haridus- ja Sotsiaalministeeriumi Kutseoskuse Osakonnale, Eesti Majandusteadlaste Seltsile ja Akadeemilisele Ühistegevuse Seltsile.

Sõnastiku seadis trükivalmis ja täiendas paarisaja sõna võrra Ed. Roos. Korrektuuris luges käesoleva oskussõnade valimiku veel kord läbi J. V. Veski, dr. E. Kant lisandas mõnikümmend sõna ja mag. E. Poom tegi arvukaid sisulisi parandusi ning kohendusi. Olgu aga siin väljendatud, et viimati-mainitu jäi nii mõneski sisulises küsimuses eriarvamusele.

Selle oskussõnastiku koostamisel on taoteldud ühtlust Eesti õigekeelsuse sõnaraamatuga“, „Eesti entsüklopeediaga“ ja „Õigusteaduse sõnastikuga“, välja arvatud mõned üksikud erinevused. Sõnaseletuste andmisel on kasutatud mõningal määral „Eesti entsüklopeediat“، ““

VMO 1935 oli täies mahus ja sama nimetuse all lisatud samal, 1935. aastal, ilmunud käsiraamatu „Ühiskaubanduse korraldus“ lõppu. Sõnastikus oli uusi või seni vähe kasutatud termineid, milleta tänapäeva majanduskirjandust on võimatu ette kujutada: ,,annuiteet“, „,brutokasum“, „kapitaalremont“, ,puhaskasum“, ,põhivara“, ,ärikahjum“jpt. Nende kõrval leidub aga selliseid oskussõnu, mida artikli autorid tollases majanduskirjanduses pole rohkem näinud: „kahjundama“ (kahjumit põhjustama) „kavent“ (käendaja), „kinnik“(kinnisvaraline ese, kinnisasi), „laegastama“ (sisse kasseerima), „laek“ (riigikassa), „loek“ (lugemine), „lõppama“ (midagi (jäädavalt) lõpetama), „lõppaja“ (isik, kes toimetab mingi ettevõtte või operatsiooni lõppamist), „müümar“ (kaubitseja, väikekaupleja turul), „orjes“ (servituut), ,oskur“ (ekspert), ,oskustus“ (ekspertiis), „pandik“ 
(pandiks antud asi), „tõht“ (efekt), „täär“ (varu, tagavara), „vallastu““ (vallasvara), ,valuteerima (tärminit, tähtpäeva märkima, millest hakatakse arvama intresse), „varastik“ (varade koostis, kõik varad kokku).

1935. aastasse jääb ka üks suur skandaal. 1933. aastal ilmus ülikooli eradotsendi Eldor Fählmanni ${ }^{4}$ raamat „Eramajanduse süsteem“. Raamatus oli tolle aja jaoks uute või harva kasutatavate terminite, nagu näiteks ,kindlad kulud“ (püsivkulud), ,otsekohesed palgad“ (põhitööliste töötasu), kõrval oskussõnu, mis on tänapäeval üldkasutatavad: „käibevarad“, „muutuvad kulud“, „,soetuskulud“, ,omakulud“ jt. Skandaal tekkis raamatu sisu tõttu. Nimelt avaldas dotsent Eduard Poom Päevalehes kolm artiklit, kus arvustas teravalt Fählmanni raamatut, väites, et see on plagiaat. Retsenseerimise stiilist annab tunnistust näiteks ühe artikli pealkiri: „Ühest teaduslikust õnnetusest ja kuritööst“. Fählmann kaebas Poomi kohtusse. Asja arutamisel jaoskonnakohtus andsid Poomi pakutud asjatundjad professor Mihail Kurtšinski, dotsent Konrad Feliks Kongo ja assistent Arnold Laagus arvamuse, mille kohaselt Fählmanni töö ,ei oma teaduslikku väärtust ja pole õpperaamatuna tarvitamiseks kohane. Teoses on tõlgitud ebatäpselt välismaa autoreid ega pole tsitaatidele juurde lisatud allikate nimetusi. Raamatus leidub ka lugematu arv lubamatuid vigu ja eksimusi“ (ÜPLÕ 1935).

Asja arutamisel ringkonnakohtus seletas kohtunik, et selle saab lõpetada leppimise teel. Poom teatas, et tema on valmis Fählmannilt vabandust paluma, kui viimane tunneb end isiklikult haavatud, kuid töö kohta avaldatud arvamistest ei saavat ta midagi tagasi võtta. Fählmann sellega nõus polnud. Poomi advokaat ütles oma kaitsekõnes, et iga teadusemees koostab vähemalt sissejuhatuse oma sõnadega, kuid Fählmannil olevat ka seegi plagieeritud (FPR 1935).

Kohtuasja puhul märkis Päevaleht (FKPR 1935): „Kuna mag. E. Poom ühe oma arwustava artikli lõpus rõhutab, et kui tema wäited dr. E. Fählmanni raamatu kohta jääwad püsima, siis tähendab see dr. E. Fählmanni kui teadusemehe surma. See näib kahekordse õigeksmõistwa otsuse peale nüüd ka nii kujunewat.“

Fählmanni kassatsioonikaebuse jättis riigikohus rahuldamata ja Fählmann pidi ülikoolist lahkuma. Tõe huvides tuleb lisada, et jaoskonna-

${ }^{4}$ Raamatu tiitellehel reklaamis Fählmann end kui „Frankfurti M. ä. Ülikooli riigiteaduste doktor, Berliini kaubandusülikooli dipl. kaupmees, Tartu ülikooli eramajandusteaduse dotsent" . 
kohtunik, kes kutsus kohtusse Poomi pakutud asjatundjad, keeldus kutsumast Fählmanni tunnistajaid - ,ppoliitilis-juriidilist raskekahurväge“ Ado Anderkoppi, Leo Seppa, Mihkel Punga ja Juhan Kukke.

Poom, kellest sai 1938. aastal Tartu Ülikooli majandusteaduskonna esimene dekaan, õpetas ülikoolis käitismajandusteadust (ettevõtteökonoomikat). Ülikooli majandusteaduskonna 1940. aastal cum laude lõpetanud Leo Tiik, kes töötas juba enne lõpetamist majandusteaduskonnas assistendina, on meenutanud Poomi järgmiselt (MHTTÜ 2015: 114):

„Häda oli sellega, et meil puudusid eestikeelsed õpperaamatud. Professor ei jõudnud ka kogu kursust süstemaatiliselt ette lugeda ja andis meile selle arvel iseseisva töö korras kirjandust läbi töötada. See oli võõrkeelne kirjandus [---] Tudeng pidi aga tundma nii saksa kui inglise keelt, muidu ülikoolis toime ei tulnud. [---] Eriti nõudlik oli Poom terminoloogia osas.“

Poomil oli vähe trükiseid. Tema magistritöö kõrval väärib märkimist 1936. aastal publitseeritud loengukonspekt „Majandusteadus“ (Poom 1936), mille uustrükk ilmus 1940. Sealt võib leida tänapäevalgi kasutatavaid termineid „käibevara“, „rentaablus“ ehk „kasumlikkus“, „püsivkulud“, „,firmaväärtus“ ehk ,goodwill“. Jäätmeid nimetas Poom ,jäänusteks“ ja konveierit ,liikuvaks töölindiks“.

Georg Grafilt ilmus 1935. aastal „Äriline kirjavahetus ja õigusteaduse käsiraamat", mille lõppu lisatud sõnastikus oli 158 terminit, ning 1940. aastal Heino Tähiste nime all „Äriline kirjavahetus“ (2. trükk, 1. trükk ilmus 1935), mille lõpus toodud sõnastikus oli 166 terminit. Grafi (Tähiste) pakutud oskussõnadest on huvitavamad „nettokasu - puhaskasum“ ja „,bruttokasu - brutokasum“, „dubioosne - kahtlane, kahtlane võlg“, „mensuaal - kuuraamat“, ,prolongeerima - pikendama, veksli tähtaega edasi lükkama“, „rekapitulatsioon - lõppkokkuvõte“, „tantieme - eritasu“. Graf on kasutanud veel liitmise tähenduses ka „kokkuarvestamist", lahutamise tähenduses ,mahaarvamist" ja korrutamise tähenduses „kasvatamist“.

Aleksander Kuke 1940. aastal ilmunud „Arveasjanduse käsiraamatus“ esineb termin „,käitisvarad“ ehk ,varud“, mille ühe alaliigina on toodud jätised (jäätmed) (A. Kukk 1940: 5). Viimaste kohta märgib Kukk: ,Jätised hinnatakse nende kasutusväärtusega või võimaliku realiseerimise väärtusega.“ (A. Kukk 1940: 14) Kukk eristas veel rakendisvara (põhivara), mis koosnes ,,vallasvarast", „kinnisvarast“ ja ,immateriaalsetest hüvistest“" (A. Kukk 1940: 4-7). 


\section{Karl Inno kui sõjaeelse Eesti Vabariigi andekaim majandusteadlane}

Omaette nähtus II maailmasõja eelses ja aegses Eesti majandusteaduses oli Karl Inno, mistõttu tutvustame teda lühidalt.

Inno lõpetas 1932. aastal cum laude Tartu Ülikooli majandusosakonna ja samal aastal ka Ühistegevuse Instituudi, magistrikraadi sai 1936. aastal (magistritöö teema „Ühistu mõiste ja liigitus“"). Inno kandideeris 1935. aastal koos Jaan Tõnissoniga õigusteaduskonna ühistegevuse õppetooli professoriks, kuid ei osutunud valituks. Olgu märgitud, et Inno esitas kandideerimisel oma asjatundlikkuse tõenduseks samal aastal ilmunud raamatu „Bilansianalüüs“ (Inno 1935), Tõnisson aga 150 lehekülge Postimehest väljalõigatud artikleid. 1938. aastal kutsuti Inno ülikooli käitismajanduse instituudi assistendiks. Sama aasta sügisel sai ta ülikooli panganduse ja kindlustusasjanduse adjunktprofessoriks, kellena töötas aastail 1938-1940 ja 1941-1944. Temalt ilmus hulk pangandust ning finantsorganite ja ühistegeliste krediidiasutuste tegevust käsitlevaid artikleid ja uurimusi. Eraldi märkimist väärivad monograafia „Bilansianalüüs“ kõrval veel mahukas käsiraamat „Pangatehnika“(1938) ning sõja ajal ilmunud „Kontoraamistik ja kuluarvestus“ (1942). Sõja ajal valmis Innol ka doktoritöö, mis jäi aga kaitsmata. Inno siirdus 1944. aasta sügisel koos perega Saksamaale, kus sai üheks eesti pagulaste juhiks. Saksamaal korraldas ta raamatupidamiskursusi, oli käitismajanduslike ainete õpetaja ning koostas eestikeelse raamatupidamisõpiku. 1950. aastal siirdus Inno koos perega USA-sse, kus töötas algul farmis põllutöölisena, kuid sai peagi erialast tööd: algul pearaamatupidaja ja büroojuhatajana firmas, seejärel, nagu märgivad Välis-Eesti allikad, aastail 1965-1974 New Yorgi osariigi majanduskomisjonis raamatupidaja ja revidendina ning arvestuse eriteadlasena. Aastail 1965-1980 oli Inno ajakirja Aja Kaja toimetaja.

Inno eristas sõna selgitust ja mõiste selgitust (Inno 1935: 13). Seda on hästi näha sõna „bilanss“ näitel. Selgitades sõna „,bilanss“ ja rõhutades, et see on levinud paljudes keeltes, märkis ta, et selle sõna päritolu suhtes arvamused lahknevad (Inno 1935: 13):

„Sõna „bilanss“ tuletatakse väga sageli itaaliakeelsest sõnast „,bilancia“" = kaal, tasakaal. Seda tõlgitsust kinnitab tegelik bilanss, mille mõlemad pooled on alati võrdsed ja seega tasakaalus. Seevastu W. Kempin tuletab sõna „,bilanss“" prantsuskeelsest sõnast ,le bilan“. Viimases „,bil“" = arvestus ja ,an“ = aasta tagasi, seega oleks selle sõna enam-vähem täpne tõlge ,aastaarvestus“, ,aastaaruanne“. See tõlgitsus tabab juba bilansi 
mõistet sisulisest küljest. Kolmandad aga tuletavad seda veel ladinakeelsest „bilanx“, mis tähendab „kahekausiline“ ja millele tuleb lisandada aja jooksul väljalangenud sõna ,libra“" = kaal.“

Raamatu kirjutamisel kasutas Inno peamiselt võõrkeelset (saksa-, inglis-, prantsus- ja venekeelset) erialakirjandust. Kuna tollal oli peamine finantsaruanne traditsiooniliselt bilanss, puudus termin uue, alles kinnistuva aruandeliigi - kasumiaruande - tähistamiseks. Teadaolevalt esimesena tuletas Inno kasumiaruande tähistamiseks uue oskussõna, milleks oli ,tulemusbilanss“.

Inno raamatutele oli iseloomulik lõppu lisatud sõnastik. See traditsioon sai alguse kohe esimesest raamatust, kust võib leida uusi või harva kasutatud termineid, mis tänapäeval on igapäevases kasutuses: „haldama“, „hoius“, „konto“ (mitte arve, nagu oldi harjutud), „olem“, „siire“, „tarvik“, „tulu“, „tõhus“, ,kasum“, „käive“, „tulem“. Muudest Inno kasutatud oskussõnadest on tänapäeval hästi tuntud „omakapital“. Ei juurdunud aga „kapitalistu“, „,kohustu“(mõlemad passiva tähenduses), „,kulum“ (puudujääk), „,tulum“ (ülejääk), „,võlgumus“ (võlgnevus), ,võlgaja“"(võlausaldaja), ,võuslema“ (liigkasu võtma), „tagam“ (garanteeriv ese, pant laiemas mõistes). Pikemalt on seletatud ,tulundus - tulutaotlus, kasumitaotlus“; ,mitte-majandusteadlased hakkasid seda oskussõna kasutama aga hoopis vääras mõistes ,majanduse“ asemel, õnneks see kasutus siiski hääbus“ (Inno 1935: 212).

Inno suur, kohati kirglik keelelembus tuleb eriti hästi esile tema kõige mahukamas teoses „Pangatehnika“, mis akadeemik Raimund Hagelbergi arvates on pangandusvaldkonnas ,kõige põhjalikum ja asjalikum, mis Eestis tänapäevani tehtud“ (Hagelberg 2007: 57) ning „on leidnud kasutamist isegi tänapäeval“" (Hagelberg, Sõrg 2003: 69). Inno märgib raamatu lõpus toodud sõnastikus (Inno 1938: 456):

„Käesolevas teoses on kasustatud eestipäraseid oskussõnu väga tagasihoidlikult, kui neid rakendatakse loodusteaduslikes, filoloogilisis jt. töis. Sellest hoolimata leidub kahtlemata teose lugejaid, kes tulevad ikkagi keele moodsuse etteheidetega. Paraku on see meie majandustegeluse maania, et siin peetakse peeneks tooniks igasugust lohisevust, ebatäpsust, teatud määral sõnade-tegemist ja karjutakse maha iga oskussõna täpsustamine ja kasustamine. Ja seda teevad samad isikud, kes järelemõtlematult ning asjatundmatult on valmis snoobitsema sõnadega ja mõistetega, mille tähendus on jäänud neile tumedaks! Meenutagem vaid meie haritlaskonna 
„tulundus“-tõbe, mil sokutati ja veelgi sokutatakse majanduse mõistes igale poole „tulundus“-sõna. Sama iseloomu kannavad ka „tööndus“-tõbi, „hankimis“"-tõbi, ,protsendi“-tõbi ja palju muudki.“5

Inno tehtud kriitika vihastas Tallinna Linnapanga pearaamatupidajat Siegfried Panti, kes oma retsensioonis Inno raamatu kohta märkis (Pant 1938: 244): „Säärast väljendusviisi on üllatav kohata teaduslikkusele pretendeerivas raamatus. See on liig isegi keskmise väärtusega poleemikas, oodatav vahest küll erakonna-agitaatori suust või sulest väljumiseks. Nii võiks väljenduda keskkooli alama klassi õpilane, kes on enam-vähem kätte õppinud kimbu uusi sõnu, üldiselt kirjutab aga üsna vigast keelt; nii võiks ka kirjutada vastutustundetu ja aluseta eneseuhke täiskasvanu ja lõppeks - nii tohib kirjutada inimene, kes tunneb keelt põhjalikult, järelikult kirjutab ise veatult, ainult - säärane inimene ei saa lubada endale seesugust eneseavaldust.“

Inno lõpetab sõnastiku, märkides (Inno 1938: 456):

„Kuna majandusteaduse alal puudub kompetentne oskussõnastik, siis osutub siin kahtlemata vajalikuks ühe või teise oskussõna täpsustamine, et ei tekiks väärarusaamist autori ja lugeja vahel. Neile on lisatud mõned sõnad üldkeelest, milliste tundmine ei ole veel üldine. Loomulikult ei saa olla järgnev sõnastik kuigi täielik ja kõiki rahuldav. Osa sõnu leiab igatahes seletuse nende esimesel rakendamisel; nende avastamiseks on kasutatav asinimestik."

Inno püüdis sõnavara korrastada, täiendada ja arendada, näiteks terminite kasutust hinnates: „kasvik - intress; lohisevas keeles: protsent“, „käive“ - „lohisevas keeles: läbikäik“. Paraku ei leidnud tema püüdlused mõistmist. Pant (1938: 241): „Milleks valida ja otsida sõnu, kui need rahvusvahelises terminoloogias on juba olemas." Ja edasi (Pant 1938: 244): „Allakirjutanu ei ole kompetentne esinema keelelise arvustajana, aga seda söandab ta oma keeletundmise alusel siiski kinnitada, et „Pangatehnika“ keel ei talu kuigi valju keelelist kriitikat. "Et millestki kinni hakata, märgib Pant (1938: 244): „Korduvalt kohtame teoses sõna ,allkirjastamine“, mis ei tähenda mitte alluvalt kirjastamist (võrd. allosakond, allüürnik jm.), vaid allakirjutamist." See kriitika on arusaamatu, sest Inno pole kuskil mõista andnud, nagu võiks allkirjastamine tähendada ka alluvalt kirjastamist.

Samas on mõnel juhul kriitikaks põhjust. Nimelt selgitas Inno terminit „,hankima“ järgmiselt: ,teisele midagi nõutama, teisele midagi üle andma,

5 Inno märgib termini „tulundus“ puhul, et see ei tähenda mitte kunagi majandust. 
teisele midagi müüma; mitte: endale nõutama, muretsema“" (Inno 1938: 456). Siin tuleb nõustuda Haljaspõlluga: „hankima“ tähendab 'soetama' (Haljaspõld 1935). Olgu märgitud, et ,hankima“ tähenduses 'muretsema, nõutama' esines juba Johannes Aaviku 1921. aastal ilmunud „Uute sõnade sõnastikus“ (Aavik 1921). Pärast II maailmasõda ilmunud eestikeelsetes majandusraamatutes (aastail 1945-1955 ilmunud eestikeelne õppekirjandus oli tõlgitud vene keelest, eestikeelseid originaaltrükiseid hakati publitseerima 1960. aastatel) kasutati eranditult venekeelsete terminite eesti vastetena sõnu ,hankimine“ ja ,hankija(d)“. Henn Saari märgib oma 1977. aastal ilmunud artiklis:

„Hang e tähenduses 'Lieferung' ja h a n k i j a 'Lieferant' leiduvad juba Eesti-õigekeelsuse-sõnaraamatus 1925. Vastuolulisus on tekkinud seetõttu, et aastakümneid tagasi ei leitud venekeelse mõiste p o s t a v i t, sks 1 i e fer $\mathrm{n}$ jaoks sobivamat vastet, kui et pöörati sõna hanki ma sellesse tähendusse. Vastuolu lahendamiseks pakuti juba 1930-ndate aastate keskel uudistüvisõna tarnima. Selle kasutamine on hoogustunud aga alles 1970-ndates aastates seoses asjaomase mõiste tähtsuse kasvuga.“ (Saari 1977: 36)

Tiiu Erelt jt (1985: 117) märgivad, et, ,tarnijad“" on vististi 1930. aastate keskel Aaviku loodud tehisverb, mis koos tuletistega on tarvitusele tulnud 1970. aastatel. Professor Uno Mereste eestvedamisel hakati alates 1980. aastate algusest eesti majanduskirjanduses ,hankijate“ asemel kasutama „tarnijaid“. Paraku toimus 1990. aastatel „,hankijate“ „taassünd“. Alates 2016. aastast on termini „tarnijad“ kasutamine seadustatud raamatupidamise seaduses.

Inno viimane ettevõtlusega seotud raamat oli sõja ajal ilmunud „Kontoraamistik ja kuluarvestus“" (1942). Raamatu lõpus toodud sõnastik on pigem eesti-saksa lühisõnastik, uusi termineid seal pole. Siiski peab Inno vajalikuks rõhutada: „,kasum - mitte kasu ega tulu“, „konto - mitte arve“, „omakulu - mitte omahind“, „tasu - mitte palk“.

\section{Kokkuvõtteks}

Majanduse oskussõnade loomine on pikaajaline protsess, mida Eestis alustati teadlikult juba 1920. aastatel. Erinevalt nüüdisterminoloogiast pöörati aastail 1920-1940 palju tähelepanu emakeelsele oskussõnavarale. Päris uute (oskus)sõnade tegemise kõrval kasutati terminite moodustamisel 
sõnade liitmist. 1940. aastaks oli eestikeelne majandusterminoloogia juba päris hea. Sellest annab tunnistust ka fakt, et tänapäeva majanduskirjanduses on kinnistunud 1930. aastatel käibele tulnud terminid ,kasumlikkus“, „brutokasum“, ,puhaskasum“, ,ärikahjum“, „tulem“, „käibevara“, „,käibevahendid“, „põhivara“, „omakapital“, ,püsivkulud“, „omahind“, „rahamajandus“, „kapitaalremont“ jmt. Poolehoidu ei ole leidnud aga näiteks ,edesraha“, „edis“, „,kooperatiivarve“, „laegastama“, „minem“, „,oodus“ ja „oodustama“, „tarbvara“, ,tulundusteadlane“, „tõht", ,,vajak“, „hüvistu“, „võlastu“"jpt.

Terminiloomeviisidest rääkides tuleb tunnistada, et palju tegeldi võõrsõnade ülevõtmise ja mugandamisega. Selliselt saadud terminitest on praegugi kasutusel näiteks ,,amortisatsioon“, ,annuiteet“, „konto“, „rentaabel“ ja ,rentaablus“. Käibelt kadunud on „baisse“, „,hausse“, „fusioon“, „gratis“, „gratifikatsioon“, „kaveerima“, „kreditiiv“", „kreposteerima“, „obligo“, „tantjeem“ ja paljud teised võõrsõnad.

\section{Kirjandus}

Aavik, Johannes 1921. Uute sõnade sõnastik. Sisaldab üle 4000 sõna. Teine parandet ja suuresti täiendet trykk. Tallinn: A. Keisermann'i kirjastus.

Adamson, J. 1922. Majandusteadus: keskkoolidele ja eneseharimiseks. Tartu: Noor-Eesti Kirjastus.

Alver, Jaan, Lehte Alver 2011a. Majandusarvestus ja rahandus I. Tallinn: Deebet. Alver, Jaan, Lehte Alver 2011b. Majandusarvestus ja rahandus II. Tallinn: Deebet.

Bogdanow, Aleksandr 1907. Lühikene majanduseteaduse õpetus. Tartu: NoorEesti kirjastus.

FKPR 1935 = Dr. E. Fählmann kaotas protsessi ka ringkonnakohtus. Päevaleht 15. VI.

FPR 1935 = Dr. E. Fählmann ja mag. E. Poom ringkonnakohtus. Postimees, 15.VI. Graf, Georg 1923. Raamatupidamise õpetus kirjateel. Tartu: J. Mällo trükk.

Graf, Georg 1935. Äriline kirjavahetus ja õigusteaduse käsiraamat. Tallinn: Praktilise raamatupidamise ja kaubandusteaduse väljaanne.

Hagelberg, Raimund 2007. Rahaasjadest ja riigi rollist nende korraldamisel. Tallinn: Eesti Pank.

Hagelberg, Raimund, Mart Sõrg 2003. 200 aastat finantsharidust Tartu Ülikoolist. - Kroon \& Majandus 4, 66-74.

Haljaspõld, Herbert 1930. Võõrsõnade leksikon. Tallinn: Elu.

Haljaspõld, Herbert 1933. Väike võõrsõnastik. Tartu: Noor-Eesti kirjastus. 
Haljaspõld, Herbert 1935. Ärielu manuaal I. Kaubanduslik terminoloogia koos saksakeelse võtmega. Tallinn: Tarbeteos.

Haljaspõld, Herbert 1937a. Entsüklopeediline võõrsõnastik. Tallinn: Raamat. Haljaspõld, Herbert 1937b. Suur võõrsõnade leksikon. Entsüklopeediline võõrsõnastik. Tallinn: Raamat.

Inno, Karl 1935. Bilansianalüüs. Ettevõtete bilansside analüüsimise käsiraamat. Tartu: Autori kirjastus.

Inno, Karl 1938. Pangatehnika. Käsiraamat eriti krediidiühistuile. I. Pangandamistehnika. Tartu.

Inno, Karl 1942. Kontoraamistik ja kuluarvestus. Raamatupidamise organiseerimise probleeme. Tartu: Eesti Kirjastus.

Jostoff, Johannes 1923. Kaubanduse korrespondents. Tartu: Noor-Eesti kirjastus.

Kukk, Aleksander 1940. Arveasjanduse käsiraamat. I. Kahekordne kirjendamine. Tallinn: Autori kirjastus.

Kukk, Johan 1929. Raamatu- ja arvepidamise käsiraamat. Tarvitajate- ja majandusühingute tegelastele. Tallinn: Eesti Ühistegelise Liidu Kirjastus.

Linnaks, Erik 1983. Raamatupidamise teooria. Tallinn: Valgus.

Moss, Eduard-Aleksander 1930. Kaubandusearitmeetika harjutistega I. Tartu: Tartu linna Tööstus- ja Majandusõpilaste kooli kirjastus.

Moss, Eduard-Aleksander 1931. Kaubandusearitmeetika harjutistega II. Tartu: Tartu linna Tööstus- ja Majandusõpilaste kooli kirjastus.

MHTTÜ 2015 = Majandusharidus ja -teadus Tartu ülikoolis. Toim. Jüri Sepp. Tartu: Eesti Ülikoolide Kirjastus.

Pant, Siegfried 1938. Karl Inno „Pangatehnika“. - Ühistegevusleht 11, 238-245.

Poom, Eduard 1936. Majandusteadus. E. Poom'ilt Kõrgema Sõjakooli sõjamajanduse ala kuulajaile peetud loengute järgi koostatud autoriseeritud konspekt: koostanud M. Uudla, R. Mägi, A. Pääbus. Tallinn: Sõjaväe Õppeasutised.

Puura, Nikolai 1929. Kaubandusaritmeetika. Tallinn: Tallinna Eesti KirjastusÜhisus.

Reichmann, Jaak 1900. Talu äriraamatud. Jurjew.

Rittich, N. 1931. Praktiline raamatupidamine iseõppimiseks. Paide: Oma kirjastusel.

Saari, Henn 1977. Hankimise asjus. - Nõukogude Õigus 1, 35-37.

Scubitz, Friedrich 1903. Kahekordse Italia Raamatupidamise Õpetus. Jurjew Tartu: Tartu: J. Kukke trükk ja kirjastus.

Sõerd, Leonhard 1923. Eesti keeles tarvitusel olevate võõrakeelsete sõnade sõnastik. Tallinn: Reklam.

Tamm, Johannes 1921. Raamatupidamise õpetus. Üldselgitus ja lihtraamatupidamine. Tallinn: Kool.

Tamm, Johannes 1923. Raamatupidamise õpetus. Kahekordne raamatupidamine. Tallinn: Tallinna Eesti Kirjastus-Ühisus. 
Tattar, A. 1902. Põlluasjanduse raamatupidamise õpetus. Jurjew - Tartu: J. Kukke trükk ja kirjastus.

Tähiste, Heino 1940. Äriline kirjavahetus. II trükk. Tallinn: Praktilise raamatupidamise ja kaubandusteaduse kursuse väljaanne.

UUS 1985 = Tiiu Erelt, Rein Kull, Henno Meriste. Uudis- ja unarsõnu. Tallinn: Valgus.

VMO 1935 = Valimik majanduslikke oskussõnu. Tallinn: Eesti Tarvitajaühistute Keskühistu Kirjastus.

ÜK 1935 = Ühiskaubanduse korraldus. Tarvitajate- ja majandusühingute organiseerimise ja asjaajamise käsiraamat. Tallinn: Eesti Tarvitajaühistute Keskühistu Kirjastus.

ÜPLÕ 1935 = Ülikooliõppejõudude protsess lõppes õigeksmõistmisega. Postimees 29. V.

Jaan Alver

majandusarvestuse instituut

majandusteaduskond

Tallinna Tehnikaülikool

Akadeemia tee 3

12618 Tallinn

jaan.alver@ttu.ee

Lehte Alver

majandusarvestuse instituut

majandusteaduskond

Tallinna Tehnikaülikool

Akadeemia tee 3

12618 Tallinn

lehte.alver@ttu.ee 


\title{
Economic terms between the two world wars
}

\author{
JAAN ALVER, LEHTE ALVER
}

The paper provides an analysis of Estonian economic terminology, including accounting terms. The first reputed Estonian bookkeeping publications, which appeared in print in 1900 and 1902, were thin booklets. The first economics and business books followed in 1907. On 1 December 1919, Tartu University opened its doors as Tartu University of the Republic of Estonia with Estonian as the language of instruction. As a result, the real development of Estonian economic terms started in the 1920s, when several business books were published. The 1930s saw further development of terminology. An important characteristic of this period is the publishing of dictionaries of foreign words as well as specialized dictionaries, including those devoted to business/commerce vocabulary. Using the right terminology was quite important, and a number of business books included small dictionaries of terms as appendices. In 1935, the Law of Language for Business Accounting came into force. By the law, from 1 January 1935 it became obligatory to keep books in Estonian. In the article, special attention is paid to Karl Inno, the most talented person in the fields of business economics, accounting and banking in the first Republic of Estonia. Inno demonstrated a thorough approach to the use of terminology throughout his writings. Although he relied on diverse sources in different languages (English, French, German, Russian and of course Estonian, his mother tongue), he was able to avoid literal translations that would carry no meaning in the Estonian language, instead coming up with reasonable Estonian terms, several of which influence their conceptual meaning in an explanatory way. Inno's terminological analysis is impressive not only as that of an accounting/ banking specialist, but also in his high-level philological approach.

Keywords: Estonian language, business economics, accounting, terminology 